\title{
Description of a model to optimise the feeding of amino acids to growing pullets
}

\author{
M.A. Bonato, N.K. Sakomura, R.M. Gous, E.P. Silva, L. Soares \& N.J. Peruzzi
}

To cite this article: M.A. Bonato, N.K. Sakomura, R.M. Gous, E.P. Silva, L. Soares \& N.J. Peruzzi (2016) Description of a model to optimise the feeding of amino acids to growing pullets, British Poultry Science, 57:1, 123-133, DOI: 10.1080/00071668.2015.1127892

To link to this article: https://doi.org/10.1080/00071668.2015.1127892

Accepted author version posted online: 06 Jan 2016. Published online: 29 Feb 2016.

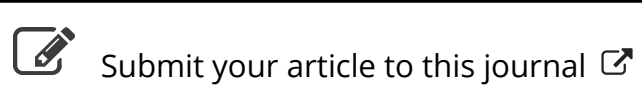

Џlll Article views: 170

View Crossmark data ¿

Citing articles: 2 View citing articles $\sqsubset$ 


\title{
Description of a model to optimise the feeding of amino acids to growing pullets
}

\author{
M.A. BONATO, N.K. SAKOMURA, R.M. GOUS ${ }^{1}$, E.P. SILVA, L. SOARES, AND N.J. PERUZZI \\ Department of Animal Sciences, São Paulo State University, UNESP, Jaboticabal, SP, Brazil, and ${ }^{1}$ School of \\ Agricultural, Earth and Environmental Sciences, University of KwaZulu-Natal, Pietermaritzburg, South Africa
}

\begin{abstract}
A nutrition model is described that may be used to optimise the amino acid nutrition of laying-type pullets prior to the onset of lay. It is not a method of optimising lifetime laying performance. 2. The potential growth and composition of the body, feathers, ovary and oviduct are described from hatching to the age at which sexual maturity is attained, from which the daily amino acid and energy requirements for the average individual in the population can be calculated.

3. There are two parts to the approach used, the first being a description of the model itself and the second being a description of how the required information was gathered. A number of assumptions made in developing the model are discussed.

4. The rates of maturing of the body, feather-free body and body protein of the DeKalb pullets used were shown to be constant at $0.017 / \mathrm{d}$ and those of feathers at $0.02 / \mathrm{d}$. These are considerably slower than those of the oviduct and ovary ( 0.139 and $0.084 / \mathrm{d}$ respectively). The ovary attained a higher mature weight (78.4 vs. $58.7 \mathrm{~g}$ ) than the oviduct.

5. The age at which the growth of the reproductive organs is initiated in the model is defined by the user. The daily amount of threonine required to meet the requirements for maintenance and potential growth of the developing tissues and organs is calculated for each day of the growing period from hatching to the age at which the first egg is laid. A method of calculating the required daily concentration of threonine in the feed is described, from which a feeding programme may be derived.

6. For the model to produce an optimum economic feeding programme for a population of laying-type pullets, more information than is available from this study is required. These issues are discussed in the paper.
\end{abstract}

\section{INTRODUCTION}

The lifetime performance of laying-type hens is largely influenced by the management of these pullets during rearing. Feeding and lighting programmes influence the age and body weight at which pullets reach sexual maturity and this has a considerable influence on the number and size of eggs produced by the hen during her lifetime (Lewis and Morris, 2006). To optimise lifetime performance, the optimum age and weight at which the flock should reach sexual maturity would need to be determined, as well as the way in which the flock should be managed during the laying period. A part of the problem of optimising lifetime performance is to determine the way in which pullets are fed during rearing so as to minimise feeding costs whilst ensuring the birds grow close to their potential to achieve the desired body weight and composition at a given age. It is this latter problem that is discussed in this paper.

Whereas the optimum economic intakes of amino acids for laying hens may be calculated from many published response experiments (Fisher et al., 1973; Pilbrow and Morris, 1974; Wethli and Morris, 1978; Gous et al., 1987) this is not the case when determining optimum levels of amino acids in feeds for pullets. Yet, this

Correspondence to: N.K. Sakomura, Department of Animal Sciences, São Paulo State University, UNESP, Jaboticabal, SP, Brazil. E-mail: 
developmental phase is important as it provides the foundation on which the reproductive performance of the hen is based. Factors to be considered in addressing this problem involve the potential growth and composition of the body, feathers, ovary and oviduct, possible changes in the efficiency of utilisation of amino acids during growth, and the age at which sexual maturity is attained, the latter defining the termination of the growth phase of a pullet.

Martin et al. (1994) published a model for calculating the daily amount of each amino acid that would be required by the average individual in a flock of growing pullets, considering separately the protein deposited in the feather-free body (FFB) and in the feathers. In their model, growth of these components was described by the Gompertz growth curve, and efficiencies of utilisation of amino acids for the growth of protein were regarded as being fixed, although this latter was not confirmed by experimentation.

In a model proposed by Silva (2012), the daily amino acid intake needed to support protein deposition in the ovary and oviduct during the growth of these organs prior to the attainment of sexual maturity was added to the model described by Martin et al. (1994). The growth of these two reproductive components has been described for broiler breeders by Bowmaker and Gous (1989). As sexual maturity may be manipulated with the use of lighting and feeding programmes (Lewis et al., 2003), the age at which the reproductive organs start growing cannot be fixed in any model, and must remain variable.

Kwakkel et al. (1995) used a different approach from that of Martin et al. (1994) by describing the different phases of growth mathematically without differentiating between the compositions of the tissues being formed. They identified four growth phases prior to the onset of laying but it is not possible with such an approach to determine the daily change in amino acid requirements of a laying pullet during growth.

The approach used here in producing a model to determine the optimum method of feeding growing pullets prior to the onset of lay is to describe the potential growth and composition of the body, feathers, ovary and oviduct from hatching to the age at which sexual maturity is attained, from which the daily amino acid and energy requirements for the average individual in the population can be calculated. This information is then used to develop an optimal feeding programme in which the under- and over-supply of amino acids during growth is minimised. There are two parts to this approach: the first is a description of the model itself and the second a description of how the required information was gathered. The data used to develop this model are from experiments conducted by Bonato et al. (2015) involving the use of threonine-limiting feeds. Studies on the amount of threonine (THR) required for maintaining body and feather protein have been reported (Bonato et al., 2011), and THR response trials have been conducted over three periods during the growth of pullets to measure body and feather protein growth, food intake and the rate of body lipid deposition resulting from the feeding of THR-limiting feeds (Bonato et al., 2015). Hence, THR is used as the reference amino acid in the development of this model.

The model described in this paper takes account of the deficiencies in the previous attempts to determine the amino acid requirements of laying pullets during the growth phase, as listed earlier, in attempting to optimise the feeding of amino acids for growing pullets.

\section{MATERIALS AND METHODS}

\section{Calculating the amino acids required for maintenance and growth}

The daily requirement for each essential amino acid is calculated for the average individual in the flock whose potential rates of body and feather protein growth are described by the Gompertz (1825) growth curve. The form of the equation used was that described by Emmans (1981) (Equation 1).

$$
P t=P_{m} \cdot e^{-e\left(\ln \left(-\ln \left(\frac{P i}{P m}\right)\right)-(B . t)\right)^{e}}
$$

where $P_{i}$ is the initial weight $(\mathrm{kg}) ; P_{m}$ is the weight at maturity $(\mathrm{kg}) ; B$ is the rate of maturing $(/ \mathrm{d})$; and $\mathrm{P} t$ is the weight of the bird at time $t$.

The rate of deposition of protein in the body and feathers was obtained by differentiating Equation 1, resulting in Equation 2:

$$
d P / d t=B \cdot P_{m} \cdot \ln \left(\frac{P_{m}}{P t}\right)
$$

Requirements are calculated separately for the feather-free body (FFB) and feathers, given that these components grow at different rates (Emmans, 1987; Hancock et al., 1995; Gous et al., 1996) and have different amino acid compositions (Emmans, 1987). The daily requirement for each amino acid is calculated as the sum of that required for maintenance of protein and for the deposition of protein in each component. This calculation is described in Equation 3: 


$$
\begin{aligned}
A A= & {\left[\left(A A m_{c} \cdot B P_{m}^{0.73} \cdot u\right)+\left(F P l \cdot F P \cdot A A_{f}\right)\right] } \\
& +\left[\left(\frac{A A_{b} \cdot B P d}{k}\right)+\left(\frac{A A_{f} \cdot F P d}{k}\right)\right]
\end{aligned}
$$

where $A A$ is the amino acid (THR in this case) requirement $(\mathrm{mg} / \mathrm{d})$ for the average bird in the population, $A A m_{c}$ is the amino acid requirement for maintenance of FFB (mg. $B P_{m}{ }^{0.73} . u$ ) (Emmans and Fisher, 1986); $B P_{m}$ is the mature body protein weight $(\mathrm{kg}), u$ is the degree of maturity of body protein $\left(u=B P_{t} / B P_{m}\right), F P l$ is the loss of feather protein $(\mathrm{g} / \mathrm{d}), F P$ is the feather protein weight at time $t(\mathrm{~g}), A A_{b}$ is the amino acid content in body protein $(\mathrm{mg} / \mathrm{g}), A A_{f}$ is the amino acid content of feather protein $(\mathrm{mg} / \mathrm{g}) ; B P d$ is the rate of body protein deposition $(\mathrm{g} / \mathrm{d}) ; F P d$ is the rate of feather protein deposition $(\mathrm{g} / \mathrm{d})$, and $k$ is the efficiency of utilisation of the amino acid for protein deposition.

In Equation 4, the additional amount required for the growth of the reproductive organs is added to Equation 3 and this would apply from the day that the growth of these organs is initiated.

$$
\begin{aligned}
A A= & E q .3+\left(\frac{A A_{b} \cdot B P d_{o v a}}{k}\right) \\
& +\left(\frac{A A_{b} \cdot B P d_{o v i}}{k}\right)
\end{aligned}
$$

The two terms added here to Equation 3 are $B P d_{o v a}$, the rate of deposition of protein in the ovary $(\mathrm{g} / \mathrm{d})$ and $B P d_{o v i}$, the rate of protein deposition in the oviduct $(\mathrm{g} / \mathrm{d})$ derived from the Gompertz growth curves describing the growth of these two organs. The constant, $k$, and the term $\mathrm{AA}_{\mathrm{b}}$ are the same as in Equation 3.

As a means of accounting for feather loss during growth, Emmans (1989) regarded the protein requirement for feather maintenance as being equivalent to the loss of feather protein at the rate of $0.01 \mathrm{~g} / \mathrm{g}$ of feathers $/ \mathrm{d}$, and the amino acid composition of protein for feather maintenance as being that of feather protein. This concept was used to calculate the amount of THR required daily for feather maintenance/loss.

The age at which the bird lays its first egg is predicted by the model of Lewis and Morris (2004), which accounts for the strain of pullet and the lighting programme used during growth (incorporating up to two changes in day length during that time). The model calculates the mean and range in ages at first egg of a population of birds from which individuals can be randomly selected.

The daily amount of THR required by a given pullet during the growing period may thus be calculated by applying Equation 3 until the age at which the growth of the reproductive organs is initiated, being approximately $42 \mathrm{~d}$ prior to the onset of laying (Lewis and Morris, 2004: see section in Discussion), whereafter Equation 4 is used. This daily amount must be converted to a dietary concentration in order to determine the THR content required in the feed, for which the amount of feed to be consumed each day needs to be predicted. Any nutrient whose daily requirement and dietary concentration is known may be used for this purpose. Emmans (1989) has justified the use of the effective energy (EE) scale when modelling energy transactions in growing birds and animals, and as the energy requirement of the growing pullet may be calculated on each day of the growing period using the data generated here, we chose to use the EE scale when calculating the daily food intake of pullets during growth.

The effective energy requirement (EERQ) of the pullet was calculated for each day of the growing period using Equation 5 (Emmans, 1989):

$$
E E R Q=M H+50 \frac{d P}{d t}+56 \frac{d L}{d t}
$$

where $E E R Q$ is the effective energy requirement $(\mathrm{MJ} / \mathrm{d}) ; \mathrm{d} P / \mathrm{d} t$ is the rate of deposition of body plus feather protein $(\mathrm{g} / \mathrm{d}) ; \mathrm{d} L / \mathrm{d} t$ is the rate of deposition of body lipid $(\mathrm{g} / \mathrm{d}) ; M H$ is the heat required for maintenance $(\mathrm{MJ} / \mathrm{d})$ given by Equation 6 from Emmans and Fisher (1986):

$$
M H=M_{E} \cdot P_{m}^{0.73} \cdot u
$$

where $M_{E}$ is $1.63 \mathrm{MJ}$, the EE needed per unit of maintenance each day; $P_{m}$ is the body protein weight at maturity $(\mathrm{kg}) ; u$ is the degree of maturity of body protein $\left(u=B P_{t} B P_{m}\right)$.

Desired food intake (DFI, g) is determined using (Equation 7) (Emmans, 1981):

$$
D F I=E E R Q / E E C
$$

where $E E C$ is the effective energy content of the feed.

For a given dietary EEC, the THR content (g/ $\mathrm{kg}$ ) in the feed that will supply the daily amount of THR required by the bird is calculated as the estimated daily THR requirement $(\mathrm{mg} / \mathrm{d})$ divided by the DFI $(\mathrm{g} / \mathrm{d})$.

\section{Determining values for the model inputs}

In the trials reported by Bonato et al. (2015), body weight $(\mathrm{BW})$, feather-free body weight (FFBW), feather weight $(\mathrm{FW})$, feather-free body protein content (BP) and feather protein content (FP) were measured in DeKalb White pullets at 0,14 , 
31, 45, 59, 72, 96 and $108 \mathrm{~d}$, and these measurements were used to describe the growth of these pullets and their components using the Gompertz growth curve. Parameter values for the fitted equations for each variable were estimated using the Gauss-Newton method, by means of the procedure "NLIN" SAS software (version 9.1).

The rate of THR deposition in each compartment (body, feather, ovary and oviduct) was obtained by multiplying the rate of protein deposition (estimated using Equation 2) by the THR content of protein in each component, as analysed in our laboratory (Bonato et al., 2015).

The efficiency of utilisation of THR for the deposition of body and feather protein was measured by Bonato et al. (2015) and this was shown to be constant over the three periods chosen, so the same value for $k(0.855)$ may be applied throughout the growing period.

Bonato et al. (2011) estimated the THR required to maintain body protein to be $75.6 \mathrm{mg} / \mathrm{BPm}^{0.73} \mathrm{u} / \mathrm{d}$, and this value was used in the calculations.

\section{RESULTS}

\section{Describing the growth and composition of the ovary and oviduct}

Silva (2012) measured the growth of the reproductive organs of DeKalb White pullets from the 15 th week $(105 \mathrm{~d})$ of age. The oviduct started growing approximately $10 \mathrm{~d}$ before the ovary, which reached a maximum weight of $77 \mathrm{~g}$ at $130 \mathrm{~d}$, and the oviduct a weight of $60 \mathrm{~g}$ at $122 \mathrm{~d}$ of age (approximately 25 and $30 \mathrm{~d}$ respectively after the initiation of growth of each organ). The first eggs were laid by these pullets when they were 21 weeks of age. Because the age at maturity may be manipulated with the use of lighting and feeding programmes, the growth of these organs for modelling purposes was assumed to start at $\mathrm{d} 0$ rather than at the ages measured in that trial. In this way, growth of these organs may be initiated at any age in the model, thereby making the model more universally applicable. Estimates of the Gompertz model parameters describing the growth of the ovary and oviduct of DeKalb pullets, based on the data of Silva (2012) and starting at $\mathrm{d} 0$ are given in Table 1. The rate of maturing ( $\mathrm{B}$ in the Gompertz equation) of the oviduct was faster than that of the ovary $(0.213$ vs. $0.111 / \mathrm{d})$ but the ovary attained a higher mature weight than the oviduct (80.0 vs. $57.8 \mathrm{~g}$ ). The rates of gain in protein in the ovary and oviduct are illustrated in Figure 1.

The changes in the chemical composition of the ovary and oviduct during the period from initiation of the growth of these organs until they reached their mature weight, measured by Silva (2012), who fitted linear regressions to these data, were used here. The fitted constant terms and regression

Table 1. Gompertz parameters describing growth of ovary and oviduct of DeKalb White pullets after initiation of growth of these organs

\begin{tabular}{lccc}
\hline & \multicolumn{3}{c}{ Parameters $^{1}$} \\
\cline { 2 - 4 } Compartment & $\mathrm{W}_{\mathrm{m}}(\mathrm{g})^{2}$ & \multicolumn{1}{c}{$\mathrm{B}(/ \mathrm{d})^{3}$} & $\mathrm{t}^{*}(\mathrm{~d})^{4}$ \\
\hline Ovary & $80.0( \pm 3.08)$ & $0.111( \pm 0.01)$ & $25.4( \pm 0.57)$ \\
Oviduct & $57.8( \pm 1.67)$ & $0.213( \pm 0.024)$ & $29.9( \pm 0.35)$ \\
\hline
\end{tabular}

${ }^{1}$ Data from Silva (2012)

${ }^{2} \mathrm{~W}_{\mathrm{m}}$ is mature weight $(\mathrm{g})$

${ }^{3} \mathrm{~B}$ is rate of maturing $(/ \mathrm{d})$.

${ }^{4} \mathrm{t}$ is age at maximum growth rate $(\mathrm{d})$.

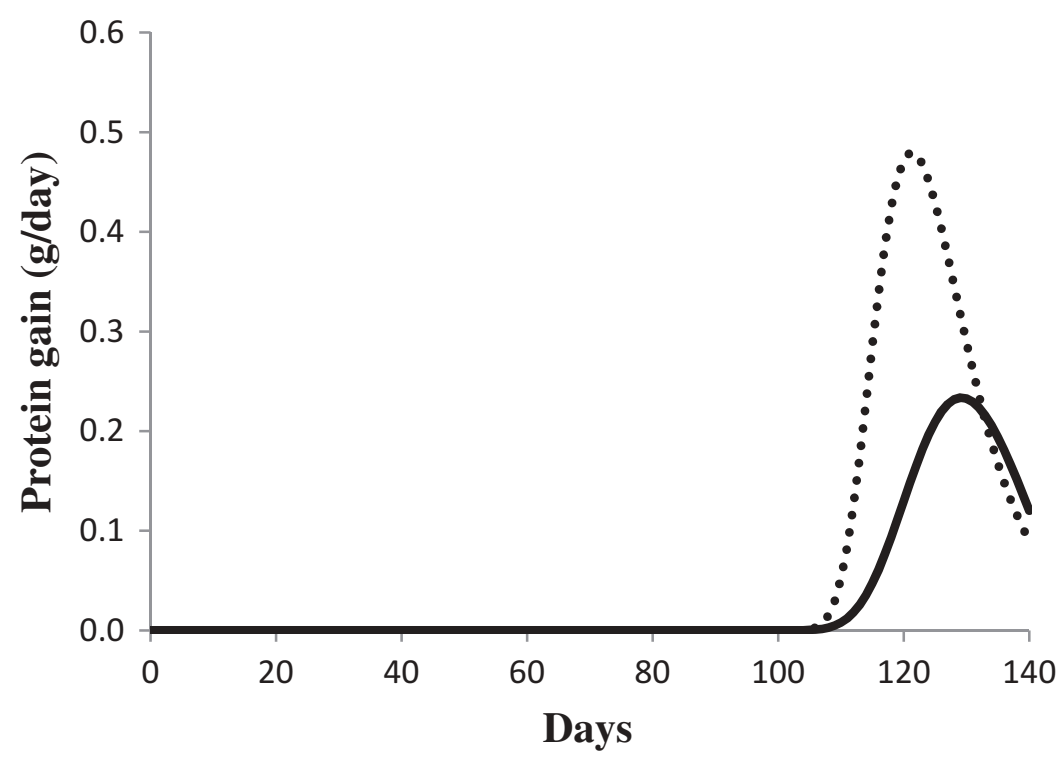

Figure 1. Rates of protein gain in the ovary (continuous line) and the oviduct (dotted line) of DeKalb White pullets estimated using the Gompertz equation. 
Table 2. Changes in the chemical composition $(\mathrm{g} / \mathrm{kg})$ of ovary and oviduct during their development, as measured by Silva (2012)

\begin{tabular}{lccccc}
\hline Organ & $\begin{array}{c}\text { Constant term } \\
\text { and SE }\end{array}$ & $\begin{array}{c}\text { Linear regression } \\
\text { and SE }\end{array}$ & $\begin{array}{c}\text { t for regression } \\
\text { coefficient }\end{array}$ \\
\hline Ovary & & & & & \\
Lipid & 75.2 & 3.09 & 0.033 & 0.024 & $0.236 \mathrm{NS}^{1}$ \\
Protein & 162 & 19.1 & -0.233 & 0.150 & $0.183 \mathrm{NS}$ \\
Water & 774 & 9.44 & -0.223 & 0.075 & $0.030 *{ }^{2}$ \\
Oviduct & & & & & \\
Lipid & 352 & 57.7 & -2.168 & 0.455 & $0.005 * *$ \\
Protein & 227 & 36.7 & -0.493 & 0.290 & $0.149 \mathrm{NS}$ \\
Water & 18.1 & 71.9 & 2.392 & 0.567 & $0.008 * *$ \\
\hline
\end{tabular}

${ }^{1}$ Not significant

${ }^{2}$ *Significant at $P<0.05, * *$ significant at $P<0.01$.

coefficients for lipid, protein and water in both organs are given in Table 2. The lipid content remained constant in the ovary over this period $(75.2 \mathrm{~g} / \mathrm{kg})$ but declined from $352 \mathrm{~g} / \mathrm{kg}$ in the oviduct at a rate of $-2.168 \mathrm{~g} / \mathrm{kg} . \mathrm{d}$, whereas the protein content in both organs remained constant, at 162 and $227 \mathrm{~g} / \mathrm{kg}$ in the ovary and oviduct respectively.

\section{Describing the growth and composition of DeKalb white pullets}

Estimates of the Gompertz model parameters describing the growth and composition of DeKalb pullets, based on the data of Bonato et al. (2015), are given in Table 3. These values were used to describe the growth in BW, FFBW, FW, BP and FP and the growth curves illustrated in Figure 2.

The rates of maturing of the body, the feather-free body and body protein were constant at $0.017 / \mathrm{d}$, whereas that for feathers and feather protein was higher $(0.020 / d)$, indicating that feathers reach their mature weight earlier than do the components of the feather-free body. The mature weight of the feather-free body was estimated to be $1450 \mathrm{~g}$ and that of feathers, $145 \mathrm{~g}$. The rates of gain in protein $(\mathrm{d} p / \mathrm{d} t)$ of the body and the feathers of DeKalb White birds to 20 weeks are illustrated in Figure 3 where the difference in the maximum growth rate between the two components, which occurs at $t^{*}$, can be observed. These ages are 80 and $68 \mathrm{~d}$ for body and feather protein, respectively.

\section{Estimating DFI, EERQ and THR requirements}

The mean EE content of the experimental diets, averaged over the three phases of the trial conducted by Bonato et al. (2015), was $10.6 \mathrm{MJ} / \mathrm{kg}$. This value was used to calculate the DFI of the average pullet in the population, based on her EERQ. The estimated daily EE and THR requirements, DFI and the required dietary THR content to ensure the desired THR intake are given in

Table 3. Estimates of the Gompertz parameters that describe the growth of the body, feather-free body, feathers and bodyand feather-protein

\begin{tabular}{lccc}
\hline & \multicolumn{3}{c}{ Gompertz parameters $^{1}$} \\
\cline { 2 - 4 } & Initial weight $(\mathrm{kg})$ & Mature weight $(\mathrm{kg})$ & Rate of maturing $(/ \mathrm{d})$ \\
\hline Body weight & $0.036( \pm 0.0010)$ & $1.60( \pm 0.191)$ & $0.017( \pm 0.0007)$ \\
Feather-free body weight & $0.034( \pm 0.0110)$ & $1.45( \pm 0.120)$ & $0.017( \pm 0.0002)$ \\
Feather weight & $0.002( \pm 0.0001)$ & $0.15( \pm 0.013)$ & $0.021( \pm 0.0004)$ \\
Body protein & $0.005( \pm 0.0003)$ & $0.26( \pm 0.020)$ & $0.017( \pm 0.0003)$ \\
Feather protein & $0.001( \pm 0.0001)$ & $0.14( \pm 0.005)$ & $0.020( \pm 0.0004)$ \\
\hline
\end{tabular}

${ }^{1} W t=W P_{m} \cdot e^{-e\left(\ln \left(-\ln \left(\frac{W_{i}}{W_{m}}\right)\right)-(B . t)\right)^{e}}$, where $W_{t}$ is the weight at time $t ; W_{i}$ is the weight at $\mathrm{d} 0(\mathrm{~kg}) ; W_{m}$ is the mature weight $(\mathrm{kg}) ; B$ is the rate of maturing $(/ \mathrm{d}) ; t$ is the age $(\mathrm{d})$.

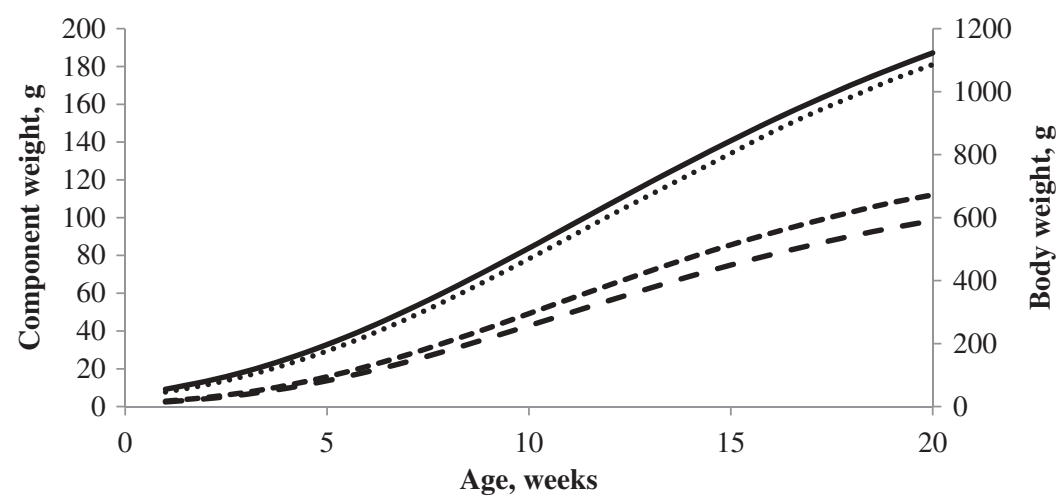

Figure 2. Growth curves depicting body weight (solid line), feather weight (- - -), feather-free body protein weight (...) and feather protein weight (- - -) of DeKalb White pullets to 20 weeks of age estimated using the Gompertz model parameters given in Table 3. 


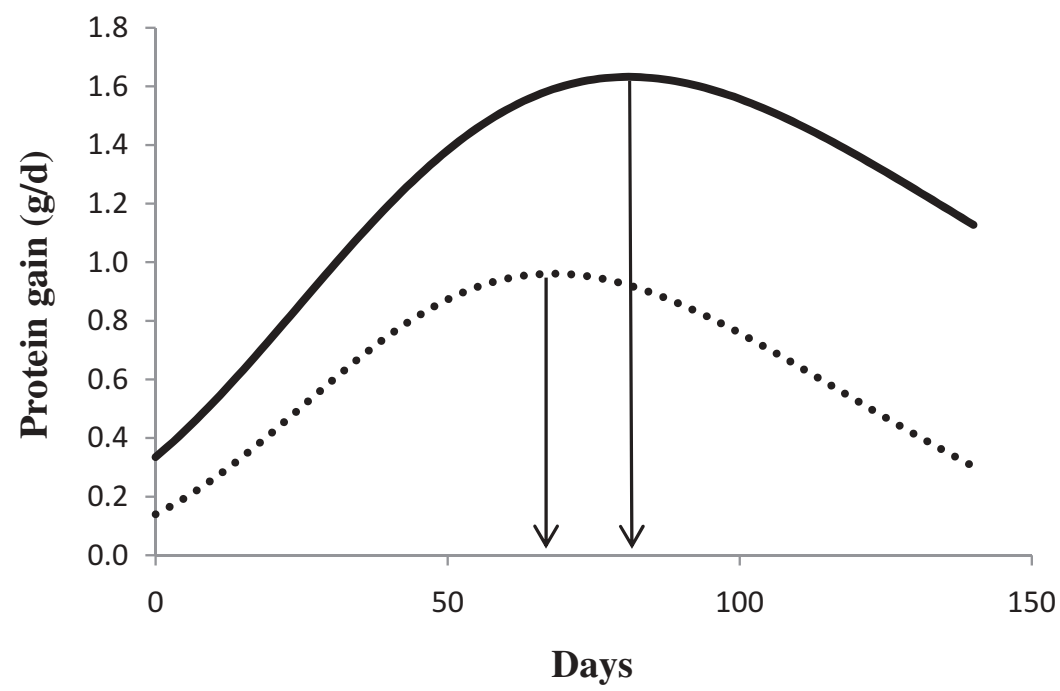

Figure 3. Rates of body (solid line) and feather protein gain (dotted line) of DeKalb White birds, estimated using the Gompertz equation to 18 weeks of age. Arrows indicate the ages at which protein growth is maximised ( $\left.t^{*}\right)$.

Table 4. A comparison of the THR requirement per $\mathrm{d}$ and per $\mathrm{kg}$ feed for DeKalb-type pullets either including or excluding that for the growth of ovary and oviduct is illustrated in Figure 4.

A summary of dietary concentrations of THR required to enable the potential growth of body, feather and reproductive organs, for each phase

Table 4. Mean estimated daily threonine (THRr) and effective energy (EERO) requirements, desired food intake (DFI) and resultant dietary threonine content (THRc) required, per week, for DeKalb-type pullets showing the differences in amounts required from 16 weeks for the growth of ovary and oviduct

\begin{tabular}{|c|c|c|c|c|c|c|c|c|}
\hline \multirow{2}{*}{$\frac{\text { Week }^{\mathrm{a}}}{1}$} & \multicolumn{2}{|c|}{$\begin{array}{l}\mathrm{THRr}^{\mathrm{b}} \\
(\mathrm{mg} / \mathrm{d})\end{array}$} & \multicolumn{2}{|c|}{$\begin{array}{c}\mathrm{EERQ}^{\mathrm{c}} \\
\mathrm{kJ} / \mathrm{d}\end{array}$} & \multicolumn{2}{|c|}{$\begin{array}{c}\mathrm{DFI}^{\mathrm{d}} \\
\mathrm{g}\end{array}$} & \multicolumn{2}{|c|}{$\begin{array}{l}\text { THRc } \\
(\mathrm{g} / \mathrm{kg})\end{array}$} \\
\hline & 36.8 & & 57.9 & & 5.5 & & 6.75 & \\
\hline 2 & 51.8 & & 80.8 & & 7.6 & & 6.80 & \\
\hline 3 & 69.5 & & 108 & & 10.2 & & 6.82 & \\
\hline 4 & 89 & & 138 & & 13.1 & & 6.81 & \\
\hline 5 & 110 & & 172 & & 16.2 & & 6.78 & \\
\hline 6 & 131 & & 206 & & 19.4 & & 6.72 & \\
\hline 7 & 151 & & 241 & & 22.7 & & 6.65 & \\
\hline 8 & 170 & & 275 & & 26.0 & & 6.55 & \\
\hline 9 & 188 & & 309 & & 29.1 & & 6.44 & \\
\hline 10 & 203 & & 341 & & 32.1 & & 6.32 & \\
\hline 11 & 216 & & 370 & & 34.9 & & 6.19 & \\
\hline 12 & 227 & & 398 & & 37.5 & & 6.05 & \\
\hline 13 & 236 & & 423 & & 39.9 & & 5.92 & \\
\hline 14 & 243 & & 446 & & 42.0 & & 5.78 & \\
\hline 15 & 248 & & 466 & & 44.0 & & 5.64 & \\
\hline 16 & 252 & 0 & 504 & 19 & 47.5 & 1.8 & 5.31 & -0.20 \\
\hline 17 & 259 & 5 & 574 & 73 & 54.2 & 6.9 & 4.79 & -0.60 \\
\hline 18 & 278 & 22 & 600 & 85 & 56.6 & 8.0 & 4.91 & -0.36 \\
\hline 19 & 295 & 38 & 603 & 75 & 56.9 & 7.1 & 5.19 & 0.03 \\
\hline 20 & 298 & 41 & 599 & 60 & 56.5 & 5.6 & 5.27 & 0.22 \\
\hline
\end{tabular}

${ }^{\mathrm{a}}$ Calculated per day and presented as average per week.

${ }^{\mathrm{b}}$ Using Equation 4, i.e. includes ovary and oviduct.

${ }^{\mathrm{c}} E E Q R=M H+50 \frac{d P}{d t}+56 \frac{d L}{d t}(\mathrm{MJ} / \mathrm{d})(5)$.

${ }^{\mathrm{d}} D F I=E E Q R / E E C(\mathrm{~g})(7)$.

${ }^{\mathrm{e}}$ THR $(\mathrm{g} / \mathrm{kg})=[($ daily estimated THR requirement $/ \mathrm{DFI})]$ based on an $\mathrm{EEC}$ of $10.6 \mathrm{MJ} / \mathrm{kg}$. for a range of dietary EE contents, is presented in Table 5, the values given being the means of the concentrations required over each period.

\section{DISCUSSION}

Essential to the optimisation of the feeding of pullets during growth is a description of their potential protein growth prior to the onset of laying. Knowing what the bird is attempting to achieve provides the information necessary to determine what the bird requires in order to achieve its goal. The purpose of the exercise reported here was to describe the potential protein growth of the average pullet, to calculate the daily intake of nutrients required to achieve that potential, and then to convert these requirements into a dietary concentration from which an optimal feeding programme could be developed. As an illustration of the technique involved, THR was used as the reference amino acid and the EE scale was used to describe the change in voluntary food intake during the growing period. Inputs to the model were from both the literature and from targeted trials conducted by the senior author to provide the information required.

The approach used in this exercise is essentially the same as that used by Martin et al. (1994) to predict the daily lysine, methionine+cysteine and tryptophan requirements of laying-type pullets during the growing period, but in that case the requirements for growth of the reproductive organs were not considered. Similarly, Bowmaker and Gous (1989) considered the growth of the reproductive organs of broiler breeders but did not account for the growth of the body prior to sexual maturity. In this exercise, the potential growth of both the body and the reproductive organs were considered when 


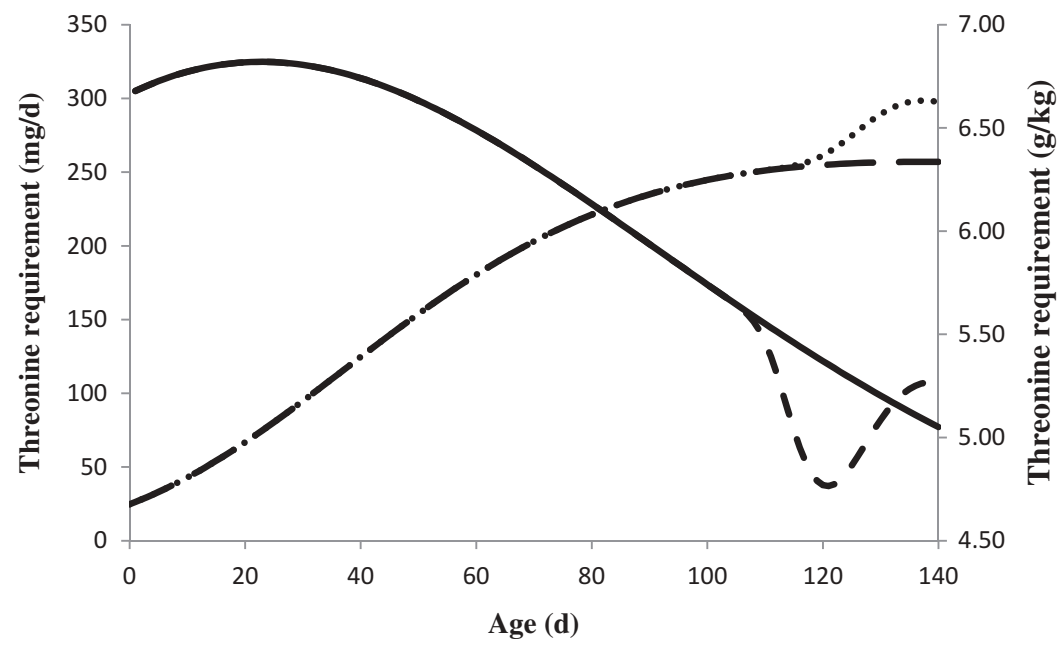

Figure 4. Estimated daily threonine requirement excluding $(\mathrm{mg} / \mathrm{d}$ - dotted and dashed line, and $\mathrm{g} / \mathrm{kg}$ - solid line) and including (mg/d - small dotted line, and $\mathrm{g} / \mathrm{kg}$ - dashed line) the growth of the ovary and oviduct, as a function of age. The required dietary THR content is calculated at an EE content of $10.5 \mathrm{MJ} / \mathrm{kg}$.

Table 5. Estimated dietary threonine content $(T H R, \mathrm{~g} / \mathrm{kg})$ required in phase 1 (1 to 6 weeks), 2 (7 to 12 weeks) and 3 (13 to 20 weeks) to support the potential protein growth of pullets for a range of dietary effective energy $(E E, M J / k g)$ contents

\begin{tabular}{lccc}
\hline \multirow{2}{*}{$\begin{array}{l}\text { TH } \\
\mathrm{MJ} / \mathrm{kg}\end{array}$} & Phase 1 & Phase 2 & Phase 3 \\
\cline { 2 - 4 } & $6.11^{1}$ & 5.77 & 4.29 \\
9.5 & 6.43 & 6.08 & 4.52 \\
10.0 & 6.76 & 6.38 & 4.75 \\
10.5 & 7.08 & 6.68 & 4.97 \\
11.0 & 7.40 & 6.99 & 5.20 \\
11.5 & 7.72 & 7.29 & 5.42 \\
12.0 & &
\end{tabular}

${ }^{1}$ Calculated as the mean of the weekly requirements over the period.

determining daily nutrient requirements in pullets prior to the onset of sexual maturity. Kwakkel et al. (1995) has also modelled the growth of the body and reproductive organs in growing pullets but the approach used in their study differed from that applied here. Their model was also based on trial data, but instead of accounting for the potential growth of the feather-free body, feathers and reproductive organs separately they fitted a series of logistic functions to the actual growth measured to produce a single, multiphasic model representing the overall growth of pullets.

A number of assumptions were made in developing the model described. These include the use of the Gompertz growth equation to describe potential protein growth, the assumption that the efficiency of utilisation of the limiting amino acid remains constant throughout the growing period, that feather development and loss is continuous throughout growth, and that the amino acid composition of protein for body and feather maintenance is that of body and feather protein respectively. These assumptions are discussed in more detail later.
The Gompertz growth curve adequately defines the potential growth of a bird, or as described by Emmans and Fisher (1986), "the upper limit to the rate of protein production". This potential growth differs from actual growth in that it is unaffected by environmental insults which would constrain growth at those times. An equation to describe actual growth would therefore require additional parameters to account for these constraints. Apart from comprising only three parameters (initial and mature body protein and the rate of maturing) the Gompertz growth curve has other useful features that make it eminently suitable in modelling growth and composition, the most useful of which is that the rate of maturing parameter is the same for all the chemical and physical components of the bird other than body lipid and feathers. This feature allows those components that share the same rate of maturing to be described allometrically from the body protein content (Emmans, 1981, 1987). Kwakkel et al. (1995) used a logistic curve to describe the growth of the pullets in his trials as this was found to fit their data with the least error, but when birds grow at their potential the maximum growth rate is reached at about 0.3 of their somatically mature weight, not half-way, as described by the logistic equation.

The assumption that the efficiency of utilisation of the limiting amino acid remains constant throughout the growing period was tested by Bonato et al. (2015) by measuring the response in body protein gain to increasing intakes of a feed limiting in THR. When measuring the efficiency of utilisation using body weight as the dependent variable the efficiencies were found to differ between periods because of differences in the rate of body lipid deposition at different ages, but where body protein gain was used the 
efficiencies remained the same throughout the growing period. Biologically this is what would be expected given that THR was the first limiting resource in the feeds and that it is being used for protein synthesis.

Feather development and loss through both wear and tear and moulting is complex and difficult to describe mathematically. From the time a bird is hatched until it becomes an adult, feathering passes through several changes of appearance due largely to the replacement of feathers and also because of the atrophy of vascular tissue which results in a loss of moisture (Latimer, 1924; Lucas and Stettenheim, 1972; Martin et al., 1994). Watson (1963) described moult in birds as a single growth process, brought about by the initiation of growth of the new generation of feathers that push the old feathers passively out of the follicles. In the absence of accurate data on the development of feathers during growth, and by measuring the weight of feathers at intervals, we have used a Gompertz growth curve to describe the growth of feathers, assuming that feather growth is continuous, and that feather loss occurs at a constant rate of $0.01 \mathrm{~g}$ feather protein/g of feathers/d (Emmans, 1989).

Bonato et al. (2011) measured the requirements for maintenance of adult roosters using the methodology described by Nonis and Gous (2008) and calculated the amount of THR in ideal body protein to be $21 \mathrm{~g} / \mathrm{kg}$. Equivalent estimates are $33 \mathrm{~g} / \mathrm{kg}$ using Leveille and Fisher (1960) values and $34 \mathrm{~g} \mathrm{THR} / \mathrm{kg}$ protein by Nonis and Gous (2008). The amount of THR in body protein is about $42 \mathrm{~g} / \mathrm{kg}$ (Emmans, 1989). Maintenance requirements are difficult to measure, and in the absence of convincing evidence to the contrary, it may be assumed that the amino acid composition of protein for body and feather maintenance is that of body and feather protein respectively, as suggested by Emmans and Fisher (1986). The amount required for maintenance is not trivial: as the bird grows the maintenance requirement becomes a greater proportion of the total required, so the accurate estimation of this component is essential if nutritional decisions are to be made on the basis of these calculations.

Although the approach used here could be termed a multiphasic approach, a term coined by Kwakkel et al. (1995), it differs from their method in respect of other than those already mentioned. They applied a multiphasic allometric function to describe the relative growth of crude protein, crude fat and ash in terms of dry matter. However, components are related allometrically only if they share the same rate of maturing (B in the Gompertz growth curve), and as the rate of maturing of both feathers and the reproductive organs were considerably faster than that of the feather-free body, the approach used by Kwakkel et al. (1995) is biologically unsound. Also, by relating the growth of the allometric components of the body to body protein rather than to body weight, differences in the lipid content of the bird are avoided, these varying from the genetically determined content due to nutritional and environmental influences (Emmans, 1981, 1987). By describing the potential growth of body protein, feather protein and the protein content of the reproductive organs, the rates of growth of the allometrically related components of the body may be calculated from these relationships. It is this approach that was used here.

Strains of laying-type pullets would be expected to differ in their mature BW, featherfree $\mathrm{BPm}$ and $\mathrm{B}$, and in the weights of feathers at maturity, because of differential selection pressures having been applied and because of the strains used as the basis of their selection. The mature weights and rates of maturing reported by Martin et al. (1994) are higher in most cases than those described here, whereas the FPm of the DeKalb White pullets was higher than those described by Martin et al. (1994) and the rate of maturing slower. By describing the potential growth rate of body and feather protein, it is possible to predict accurately the daily intakes of amino acid and energy required for growth of these different strains.

Regarding the growth of the reproductive organs, very few data are available for comparative purposes. In the Kwakkel et al. (1995) study, the duration of what they termed the mature growth spurt (representing the period of growth of the reproductive organs) was between 5.2 and 6.7 weeks, and the organs that developed during this time weighed between 169 and $263 \mathrm{~g}$ at maturity, with the age at maximum gain occurring between 19.2 and 20.3 weeks (or approximately 3 weeks after the growth of these organs was initiated) depending on the nutritional treatment imposed during rearing. In the present study the mature weight of these organs was estimated to be reached between 10 and 13 weeks after growth was initiated (approximately $t^{*} \times 3$ ), or at 180 and $195 \mathrm{~d}$, respectively. The organs were predicted to weigh $138 \mathrm{~g}$ at maturity. Bowmaker and Gous (1989) used broiler breeders in their study and concluded that the age at maturity of both organs occurred at $168 \mathrm{~d}$. In spite of the large difference in the age at maturity of these breeds (see Lewis et al., 2003, 2007) the age at maturity of the reproductive organs appears to be similar.

Because the age at sexual maturity in a flock of laying pullets can be manipulated with the use of lighting and feeding programmes (Lewis et al., 2003) the age at which the reproductive organs begin to develop should not be fixed in a model to predict the nutrient requirements of a flock of pullets during growth. Once the majority of the 
flock has started laying, nutrient requirements change and need to be dealt with using a different approach to that used here. It is presumed in this case that 0.5 of a flock of laying-type pullets would reach sexual maturity by 20 weeks of age, causing body and feather protein growth to cease at that age (Nonis and Gous, 2015). In the model developed here, the age at which the ovary and oviduct begin to develop is user controlled; hence the model is sufficiently versatile to account for changes in age at sexual maturity in the flock. The model of Lewis and Morris (2004) predicts the age at maturity (mean and SD) of pullets subjected to one or two changes in day length during rearing, but the growth of these organs begins some time prior to the first egg being laid, so this period needs to be accounted for when specifying the age at which the growth of these organs is initiated. In Table $1, t^{*}$ is between 25 and $30 \mathrm{~d}$, so the initiation of the growth of these organs must occur at least 4 to 6 weeks before the first egg is laid, although this growth would only be detectable, and hence important from a nutritional point of view, closer to the period of maximum growth $\left(t^{*}\right)$. The first eggs were laid $42 \mathrm{~d}$ after the initiation of growth of the ovary and oviduct, this being approximately $7 \mathrm{~d}$ after the organs were growing at their maximum rate $\left(t^{*}\right)$, indicating that these organs need not be mature before egg production will commence. This aspect might be worth investigating further.

The calculation of a daily DFI based on an $\mathrm{EE}$ requirement and the $\mathrm{EE}$ content of the feed is a way of estimating the food intake of pullets during the growing period, from which it is possible to determine the dietary amino acid concentration needed to support the potential growth of the pullet. This is not to imply that birds regulate their feed intake according to the energy content of the feed, but assumes (Emmans, 1989) that a bird will attempt to consume sufficient of a given feed to meet the requirement for the first-limiting resource in the feed. In this case, EE is made to be the limiting feed resource, and the amino acid content of the feed is then calculated on the basis of the amount of food to be eaten to satisfy the EE requirement. Because the resultant amino acid contents are related to the EE content chosen, the EE content used would need to be specified when formulating the pullet feeds.

The decline in the dietary THR content required when the growth of the reproductive organs is included in the calculation of requirement deserves mention. The daily requirement for THR to meet the needs for ovary and oviduct growth is considerably less than the EE requirement for the same purpose, reflecting the greater demand for lipid than for protein growth in these organs. Because food intake would need to increase to meet the higher EE requirement less THR would be needed in the feed during this period in spite of the increased THR requirement.

Examples of the mean THR contents in each of three phases are given in Table 5 for a range of EECs, which were used to predict DFI and hence THR content. A conventional three-phase approach may not be the most appropriate from a nutritional point of view. For some amino acids the requirements of the pullet change more rapidly early on during growth and then remain relatively constant later, and for these amino acids their requirements may be more accurately matched if, for example, a different feeding schedule is used. As it is not practical to change the composition of the feed daily, the growing period must be subdivided into different phases during each of which a unique feed is offered. For a standard feeding programme there will necessarily be periods within each phase during which the pullets will be under- and over-fed protein (THR) in relation to the energy content supplied. In attempting to consume sufficient of the limiting resource (Emmans, 1989) the pullets would need to overconsume resources that are not limiting, such as energy, and there is evidence that this happens in broilers (Gous et al., 1990). However, the extent to which birds can overconsume energy varies between genotypes (Kemp et al., 2005; Berhe and Gous, 2008) and this impacts on their response to feeds with a low protein:energy ratio. Lean genotypes are incapable of depositing large amounts of energy as body lipid; hence their intake of a low protein food will be lower than that of a fat genotype. The pullets used by Bonato et al. (2015) that were fed diets with low THR contents could not compensate for the low concentration of this amino acid by consuming more feed; hence their body weight gains were considerably compromised by the low dietary THR content. Although the required dietary THR content remains relatively constant in the first phase, this changes considerably throughout phases 2 and 3, as illustrated in Figure 4, and by choosing a dietary THR content in the lower half of the range in each period it is possible that pullets at the start of phases 2 and 3 will be incapable of consuming the amount of THR required because these pullets do not seem to be capable of overconsuming energy. Under such circumstances an additional phase might be worth considering, thereby matching the dietary amino acid contents more closely with those required by the pullet.

Although the aforementioned approach appears to be nutritionally sensible it may not be the optimum economic approach. A decision as to the optimum THR content for each phase needs to be made, and this could be on a biological, 
nutritional and/or economic basis. The length of each phase could also be adjusted to match more accurately the daily THR requirement of the bird. These are options that may be explored when the daily requirement for amino acids and energy are known, leading to the optimum economic feeding programme to be used during the growing period. To optimise the feeding programme it is necessary to consider the cost of feeding different levels of THR (and other amino acids) for different lengths of time, i.e. optimising both the nutrient density and the feeding programme. This requires more information than is available from this study: for example, the actual food intake may not match the desired feed consumption because of bulk or environmental constraints (Emmans, 1989). Furthermore, the consequences of underand over-feeding amino acids are not considered here, nor are the effects of body composition on subsequent egg production.

The model proposed in this paper provides a reliable means of estimating the daily amino acid and $\mathrm{EE}$ requirements of a pullet during growth, and describes how these requirements can be converted into nutrient concentrations. However, the optimisation of a feeding programme for growing pullets requires more information than is available from these studies. Specifically, it is necessary to know the extent to which body composition at point-of-lay influences subsequent reproductive performance, the extent to which a pullet can overconsume energy in an attempt to obtain sufficient of the limiting nutrient in the feed, and the constraining effects of feed bulk and environmental heat demand on the ability of a pullet to consume its desired food intake each day. In addition, the model should reflect the variation that occurs in growth rate and the age at which pullets become sexually mature, rather than characterising only the average individual in the population. Such a stochastic approach is possible, using appropriate means and standard deviations for the relevant parameters, but only once the response of an individual is accurately predicted. In spite of the lack of such information, the model proposed here is a useful step towards the development of a means of determining the optimum economic method of feeding a population of growing pullets.

\section{DISCLOSURE STATEMENT}

No potential conflict of interest was reported by the authors.

\section{FUNDING}

We wish to acknowledge the financial support for this research and the scholarship awarded to the senior author from the Fundação de Apoio à Pesquisa do Estado de São Paulo (FAPESP).

\section{REFERENCES}

BerHe, E.T. \& Gous, R.M. (2008) Effect of dietary protein content on growth, uniformity and mortality of two commercial broiler strains. South African Journal of Animal Science, 38: 293-302.

Bonato, M.A., Sakomura, N.K., Gous, R.M., Dourado, L.R.B., Rafael, J.M. \& Fernandes, J.B.K. (2015) The response to dietary threonine in laying-type pullets during growth. British Poultry Science, 56: 361-369. doi:10.1080/ 00071668.2015.1019425

Bonato, M.A., Sakomura, N.K., Siqueira, J.C., Fernandes, J.B.K. \& Gous, R.M. (2011) Maintenance requirements for methionine and cysteine, and threonine for poultry. South African Journal of Animal Science, 41: 209-222.

BowMAKer, J.E. \& Gous, R.M. (1989) Quantification of reproductive changes and nutrient requirements of broiler breeder pullets at sexual maturity. British Poultry Science, 30: 663676. doi: $10.1080 / 00071668908417189$

Emmans, G.C. (1981) A model of the growth and feed intake of ad libitum fed animals, particularly poultry, in: HILLYER, G.M., Whiltemore, C.T. and Gunn, P.G. (Eds.), Computers in Animal Production, pp. 103-110 (Occasional Publication No. 5. British Society of Animal Production).

Emmans, G.C. (1987) Growth, body composition and feed intake. World's Poultry Science Journal, 43: 208-227. doi:10.1079/WPS19870014

Emmans, G.C. (1989) The growth of turkeys, in: Nixey, C. \& Grey, T.C. (Eds) Recent Advances in Turkey Science, pp. 135166 (London, Butterworths).

Emmans, G.C. \& Fisher, C. (1986) Problems in nutritional theory, in: Fisher, C. \& Boorman, K.N. (Eds) Nutritional Requirements and Nutritional Theory, pp. 9-39 (London, Butterworths).

Fisher, C., Morris, T.R. \& Jennings, R.C. (1973) A model for the description and prediction of the response of laying hens to amino acid intake. British Poultry Science, 14: 469484. doi:10.1080/00071667308416054

GOMPERTZ, B. (1825) On the nature of the function expressive of the law of human mortality, and on a new mode of determining the value of life contingencies. Philosophical Transactions of the Royal Society of London, 115: 513-583. doi:10.1098/rstl.1825.0026

Gous, R.M., Emmans, G.C., Broadbent, L.A. \& Fisher, C. (1990) Nutritional effects on the growth and fatness of broilers. British Poultry Science, 31: 495-505. doi:10.1080/00071669008417281

Gous, R.M., Griessel, M. \& MorRis, T.R. (1987) Effect of dietary energy concentration on the response of laying hens to amino acids. British Poultry Science, 28: 427-436. doi:10.1080/ 00071668708416977

Gous, R.M., Pym, R.A.E., Mannion, P. \& Wu, J.X. (1996) An evaluation of the parameters of the Gompertz growth equation that describe the growth of eight strains of broiler. Australian Poultry Science Symposium, University of Sydney, Sydney, NSW, Vol. 8, pp. 174-177.

Hancock, C.E., Bradford, G.D., Emmans, G.C. \& Gous, R.M. (1995) The evaluation of the growth parameters of six strains of commercial broiler chickens. British Poultry Science, 36: 247-264. doi:10.1080/00071669508417773

Kemp, C., Fisher, C. \& Kenny, M. (2005) Genotype - nutrition interactions in broilers; response to balanced protein in two commercial strains. 15th European Symposium on Poultry Nutrition, Balatonfüred, Hungary, pp 54-56.

Kwakkel, R.P., Van Esch, J.A.W., Ducro, B.J. \& Koops, W.J. (1995) Onset of lay related to multiphasic growth and body composition in white Leghorn pullets provided ad 
libitum and restricted diets. Poultry Science, 74: 821-832. doi:10.3382/ps.0740821

Latimer, H.B. (1924) Postnatal growth of the body, systems and organs of the single-conb White Leghorn chicken. Journal of Agricultural Research, 29: 363-397.

Leveille, G.A. \& Fisher, H. (1960) Amino acid requirements for maintenance in the adult rooster III. The requirements for leucine, isoleucine, valine and threonine, with reference also to the utilization of the d-isomers of valine, threonine and isoleucine. Journal of Nutrition, 70: 135-140.

Lewis, P.D., Ciacciariello, M. \& Gous, R.M. (2003) Photorefractoriness in broiler breeders: sexual maturity and egg production evidence. British Poultry Science, 44: 634-642. doi:10.1080/00071660310001616219

Lewis, P.D., Gous, R.M. \& Morris, T.R. (2007) Model to predict age at sexual maturity in broiler breeders given a single increment in photoperiod. British Poultry Science, 48: 625634. doi:10.1080/00071660701573060

LEWIS, P.D. \& MorRIS, T.R. (2004) Research note: amendments to the model for predicting age at sexual maturity for growing pullets of layer strains following changes in photoperiod. The Journal of Agricultural Science, 142: 613-614. doi:10.1017/S002185960400471X

LEwIS, P.D. \& MorRIS, T.R. (2006) Lighting for growing pullets and laying hens, in: Poultry Lighting, the Theory and Practice pp. 121-136 (Andover, Northcot).
Lucas, A.M. \& Stettenheim, P.R. (1972) Avian Anatomy Integument Part I, Agricultural Handbook 362 (East Lansing, ARS USDA in Cooperation with Michigan Agricultural Experiment Station). Martin, P.A., Bradford, G.D. \& Gous, R.M. (1994) A formal method of determining the dietary amino acid requirements of laying type pullets during their growing period. British Poultry Science, 35: 709-724. doi:10.1080/00071669408417737

NonIs, M.K. \& Gous, R.M. (2008) Threonine and lysine requirements for maintenance in chickens. South African Journal of Animal Science, 38: 75-82.

Nonis, M.K. \& Gous, R.M. (2015) Changes in the feather-free body of broiler breeder hens after sexual maturity. Animal Production Science, (in press). doi:10.1071/AN14713

Pilbrow, P.J. \& Morris, T.R. (1974) Comparison of lysine requirements amongst eight stocks of laying fowl. British Poultry Science, 15: 51-73. doi:10.1080/00071667408416081

SIIVA, E.P. (2012) Modelos de crescimento e das respostas de frangas de postura submetidas a diferentes ingestões de aminoácidos sulfurados (Jaboticabal, 207f. Tese (Doutorado em Zootecnia) Universidade Estadual Paulista "Julio de Mesquita Filho").

Watson, G.E. (1963) The mechanism of feather replacement during natural molt. The Auk, 80: 486-495. doi:10.2307/ 4082854

Wethli, E. \& Morris, T.R. (1978) Effects of age on the tryptophan requirement of laying hens. British Poultry Science, 19: 559-565. doi:10.1080/00071667808416513 